\title{
Media Literacy and the Broadcast "Nation": Making Sense of What We Have Signed on For
}

\author{
Karen Weaver \\ Drexel University
}

In this paper, the author provides a response to Dunn (2013) and Martin (2013). Focusing on the relationship between the media and intercollegiate sport, the author examined the impact of intercollegiate athletics on the finances, mission, and outcomes of the broader institutions in which they are housed. Recommendations for future action are offered.

For the past two and half years, college sports have been in a frenzy. Like the anticipation of buying a new car, we have been kicking the tires, reading our consumer reports, and discussing the bottom line of all of the television network deals that have been consummated. From the NCAA's $\$ 10.8$ billion deal with CBS/ Turner to ESPN's National Championship broadcasting agreement for 12 years at $\$ 7.3$ billion, to the Big Ten and Pac-12 launching their own television networks, we have been in a digital frenzy (Chen, 2012; Martin, 2013). Rather than discussing graduation rates and other academic issues, the new world order includes terms such as "distribution channels," "brand loyalty," and "media markets." Journalists have been analyzing the winners and losers in these deals, from the networks to the conferences and beyond. The staggering amount of money being redirected to higher education in the US today is unprecedented (Nocera, 2012).

But just exactly what have we signed on for in developing these partnerships? Are we fully informed as to what the tradeoffs are? Like diligent consumers, did we read the "fine print" and carefully consider it, or, in our excitement to drive our new car, did we sign on the dotted line, rush out the door and drive off the lot in our shiny new sports car?

Here is a quick history lesson for those who have not been able to keep up (and one could presume there are more than a few). Technology changes in the past 12 years have created a "new world order" of demand for content. Sports channels (and for that matter, any other type of channel whether it be home improvement or sappy movies) are being launched at amazing rate. A channel needs something to air (called content) and an audience to watch (called the demographics). It makes money from being distributed on cable and satellite TV (like Comcast and Direct TV) and from selling advertisements. (Ey, 2013; Ourand, 2009; Stelter, 2013; Weaver, 2009). The math is simple: the more attractive the demographics, the

Weaver is with Goodwin College at Drexel University, Philadelphia, PA. 
more folks watch and the more companies can charge both the distributors and the advertisers. Colleges have been happy to "sell" the broadcast rights to their games, and sports channels have been willing to write the checks. When a team becomes popular and has multiple suitors, the price goes up. It is capitalism at its most fundamental.

Enter the "niche" channel, tailored to a smaller but more engaged demographic: hard core fans. In this age of over 500 channels on our cable screens, there are hundreds of them. From Latino to soccer, from racing to reality, there are more channels than ever before. The Big Ten Network, launched in 2007, capitalized on this trend. Realizing there was a large, loyal following in the 8 state footprint of the Big Ten Conference, the network began with humble beginnings and major distribution challenges. Critics asked, "Who would watch a network with second rate college football games and volleyball games?" It was almost universally panned as a loser from the gate. Yet, beginning with their first weekend of broadcasting, which included the first "upset" of the year between Appalachian State and Michigan in football, the Network has steadily found its voice and, more importantly, its reach. It is now in almost 50 million homes (Carmin, 2012; Chen, 2012; Weaver, 2009, 2011)

The Big Ten Network spawned the Pac-12 Network, which led to the Longhorn Network, and the SEC announced the creation of the SEC network in May 2013, and will launch it in August 2014. The "realignment" of schools to conferences that have lucrative television packages has been one of the best soap operas around recently. I can hear the announcer now:

Tune in tomorrow for the continuing saga of As the College Sports World Turns... Will Texas A\&M stay with their old love in the Big 12 or pursue the big man on campus, the SEC? Will Oklahoma and Texas leave their Southwestern roots for a new Hollywood lifestyle? And will Maryland ever be able to balance their athletics budget?"

Who needs reality TV when you have college sports media intrigue (Clarke, 2012; Dowd, 2012; Eshelman, 2012)?

Ladies and gentlemen, it is time to read the fine print. The car has a few thousand miles on it and will eventually lose its "newness." The dealer has moved on and your first few payments are due. To whom did we just get married?

Martin (2013) and Dunn (2013) spoke eloquently about the need to set examples as educators and leaders. I agree, and the first step is to lay the cards out on the table and learn what we do not know. In this paper, I provide such an analysis by considering evidence in three categories: the finances, the mission, and the outcome.

\section{Finances}

Years ago, athletics administrators worried that radio and TV broadcasts would dilute the marketplace and cause ticket sales to go down. Since ticket sales were the primary means of revenue for an athletics budget, that was a legitimate concern (Smith, 2001). Today, selling tickets and hot dogs is only a small fraction of a BCS schools' revenue. Some would argue that ticket prices are probably capped out in individual markets, and schools will have a bigger challenge in leasing those luxury boxes they built in the $90 \mathrm{~s}$. There are too many things competing for our attention 
on the weekends. Television, though, is where the growth is. The "in home" viewing experience, with the advent of HD TV, has made it so superior, athletic directors are starting to realize they may not have to build out a stadium and add more seats to gain more revenue; instead, they will need to reach more homes through better distribution (Chen, 2012). The remarkable thing about this is, it is almost all profit, with little to no infrastructure improvements required once you build out the technology. Professional sports realize they will have to keep fans coming to the games through a superior "in game" experience. College sports have not yet truly embraced that philosophy. Add to all of that the explosion of "second screens"additional engagement through iPads, laptops and smartphones, and the viewing experience (and the need for content) multiplies exponentially (Thompson, 2012).

Fort and Quirk (1995) analyzed the market sensitivity that these national broadcast agreements have in impacting the competitive balance of teams in professional sports. On the whole, national broadcasts revenue is greater when large market teams reach the league championship series because more viewers are looking for the result. Indeed, the 2012 National Championship game between Alabama and Notre Dame scored a 15.7 rating, a 14\% increase over last year's game. Two compelling teams with rich traditions was the story, and it was \#1 vs \#2. The hype leading up to the game was tremendous, but the game was a blow out. However, because the numbers went up, this validates the investment that broadcast networks make in college sports. The bottom has not fallen out, yet.

But here is the trade-off Fort and Quirk (1995) note: league-wide agreements imply a transfer of wealth between the more successful teams and the less successful teams. This transfer enables the leagues to stay together. However, teams with a true national reach (as the Big Ten Conference and the Big East Conference appear to be doing), helps to keep the marginal teams in business and forecloses on any teams entering into their markets. The SEC has practiced a form of this for years by primarily selecting one institution per state within their footprint. This economic theory runs counter to Division I current composition and creates the economic imbalance that is so obvious in today's discussions.

These revenues that colleges receive are built around the concept of wide ranging distribution (i.e., the channel or program is available to the most number of people). The term "basic tier" represents the bull's eye that nearly every content provider wants to hit, as the largest number of people subscribes to basic cable or satellite. Where the battles come is when a distributor decides to place the channel on a sports tier. In this case, consumers will have to make a choice as to whether they will pay the extra monthly fee for a bundle of "premium" sports channels (Flint, 2012; Goetzl, 2012; Steller, 2012). This is often the first to go when a consumer is trying to manage a tight budget. If cable systems and sports networks battle over where the channel will live, the consumer can be the loser. It took the Big Ten Network almost a full year to gain distribution on Comcast, one of the country's largest cable systems. Some have argued that it was because Comcast only gave priority to the sports networks in which it has ownership. While that is a violation of the Federal Communication Commission's guidelines, it certainly meant that consumers were on the outside looking in during that time (Weaver, 2009).

What is less understood in these rushes to sign long term deals is something more insidious: the longer term disincentive conferences have to go back to the marketplace when the deal is close to expiring (Cave \& Crandall, 2001). Consider the 
Big Ten Network's partnership with Fox and the Longhorn Network's partnership with ESPN. Both media partners agreed on the front end to incur substantial costs in building out the infrastructure. From HD studios, to high speed transmission lines, to on campus TV studios, the networks absorbed these costs, and in the case of Fox and the Big Ten Network, also paid a substantial "welcome to the family" payment of $\$ 3$ million per school in year one. The Big Ten agreement is for 20 years with an agreement that schools will also receive 33\% of the net profits (Ourand, 2009; Weaver 2009). In recent news accounts surrounding the addition of Maryland and Rutgers to the Big Ten Conference, insiders were quoted as saying the annual per school payout from their media rights would approach $\$ 41$ million in 2017 (Clarke, 2012; Politi, 2012). In just 10 years, a school in the Big Ten grew the revenue side of the budget from media deals by fourfold. But when they go back to the market, Roger Noll (2007) in his article "Broadcasting and Team Sports" argues that is when the money drops off. Because of the long term relationships established by these parties, there is less of an inclination to place the entire arrangement back out in the true marketplace. Therefore, the second time around, conferences do not act in a way that is truly capitalistic. Instead, they shy away from seeking out the most lucrative financial deal available in the market for a continuation of the existing relationship, driving down the ultimate value of the deal (Noll, 2007). When discussing billions of dollars, this is a substantial pattern of which to be aware. Media companies, aware that they have to build in their business efficiencies in the front of the contract, create the perception of a "toe hold" to other potential bidders. Because they know their partner so well, the content providers are less likely to switch to a new dance partner. It will be a matter of time to see if the Big Ten stays with Fox and the Longhorn Network stays with ESPN. As a side note, this is where the Pac-12 network differs, as it is a wholly owned company of the Pac 12 Conference (Flint, 2012). They assumed all the financial risk and all the rewards.

One more thing when it comes to finance: many of the BCS schools are land grant colleges and universities supported to some degree by the citizens of the state. Citizen taxpayers have yet to complain too loudly about being taxed twice by their public universities: first by the general appropriations made by the legislative bodies and secondly by the size of their cable bills (Ey, 2013). How much longer that will be the case is anyone's guess.

\section{Mission}

The second point to consider is that of mission. Fundamentally, the mission of higher education is to educate. Contrast that with the mission of a media company. In an internal memo, former Walt Disney Co CEO Michael Eisner expressed the following: "We have no obligation to make history; we have no obligation to make art; we have no obligation to make a statement; to make money is our only objective" (Newsom, 2012). Indeed, these media companies are making a lot of money. While the numbers coming into higher education seem staggering, consider this-in just six quarters, Fox turned a multimillion dollar profit on the Big Ten Network (Ourand, 2009; Weaver, 2011). Despite all the distribution battles, despite the initial "signing bonus" provided to all 11 universities, and despite launching in the worst 
economic environment to begin a new venture in since the Great Depression, Fox made millions on its new channel. Imagine what those numbers look like today without those initial costs. If each school is making \$16m a year in 2011-12 just from the network, Fox is making more. Higher education professionals would not begrudge a company having some profit; what we have failed to grasp is the size of these profits for media companies. Their efficiencies are so entrenched, the numbers are staggering, even with the payouts growing each year. When put into context with the issues surrounding paying student athletes and the explosion of coaching and administrative salaries (Nocera, 2012), the conversation is not being had about how much the media companies are making off of us.

\section{Outcomes}

Finally, and most importantly, the outcomes of these partnerships, both intended and unintended, are starting to appear. The espoused values of our academic leaders are giving way to economic realities of partnering with a media partner whose sole purpose is to make money. Early on, the Big Ten Network promoted the fact that $660 \mathrm{hr}$ per year would be devoted to nonsports (or academic) programming (Weaver, 2009). After experiencing extremely low ratings (and sometimes marginal cooperation from the academic community on some campuses), this went out the window in 2011. Instead, we have more "shoulder" programming around football, and more Student "U" productions (Kaszuba, 2013). The "professional" quality of the commentary and limited production characteristics that go into the nonfootball events creates a different broadcast. Whether that matters to us should be a topic of discussion. This year, the network began having its in-game talent cover many games from the Chicago studios rather than traveling to the site of the game. They were not alone, as NBC did the same in its Olympic coverage of lower profile sports this summer.

More concerning is the obvious disconnect between the media business' values and the academic community's values. Most colleges and universities have for some years been experiencing a renaissance of sort with regards to the hiring and promotion of women and minorities to visible high ranking positions on our campuses and within the NCAA. In fact, the NCAA has taken a leadership position on this issue and put substantial effort into hiring women and minorities on their own staff, as well as educating the academic world about the good that diversity can do in providing a real world example to educate our students (SBJ, 2006). But step inside of media companies, including the ones we are doing business with, and the world looks like the 1950s. Women and minorities are few and far between. Here are some statistics: at the highest levels of some of these media conglomerates, women comprise less than 5\% of board positions: Time Warner 2 of 13; CBS 2 of 14; Disney 4 of 13; NBC 4 of 17; Viacom 2 of 11; Fox 1 of 16 . Across the highest levels, women hold $3 \%$ of the "power" positions in determining programming and content positions (Newsom, 2012). Minorities do not even register as a percentage in these critical positions in these companies.

The focus of this colloquium is on the financial inequities in Division I athletics. Within the marketplace as it exists today, these inequities have grown to enormous 
proportions, directly impacting the student athlete experience from school to school. What has been thoroughly discussed and speculated in the media involves this idea of conference realignment as a disruptive event in the renegotiations of TV contracts (Eshelman, 2012; Politi, 2012; Puskar, 2012). Add or lose a school? Go back to the table and renegotiate a new deal. This is exactly what has been the dynamic for the Big East, where a lack of stability has caused a constantly changing value to be assigned to the TV rights deals (Johnston, 2012; Vorkunov, 2012). But what if another market disruption caused a different effect?

Academics and athletic directors would be wise to presume that technological changes will continue at a rapid pace and that, one of these days, a disruptive event will occur that may change the current economic model that has created profits. Certainly, the advent of second screens and other digital content devices has been a new force to contend with. But what if the distribution model changes? Burke Magnus, Senior Vice President of College Sports Programming at ESPN, told the audience at the Intercollegiate Athletics Forum in New York City stated "our business hates uncertainty" (2012). Yet, they know that technological changes are coming. One of the models that cable companies have been able to control is distribution. If you are not on a cable companies channel guide, it is as if your channel does not exist. Yet venture capitalists are funding new companies whose focus is on eliminating the cable systems as the middlemen. Instead, they are developing the technology that allows you and me to create a personal distribution network with our smartphones (Magnus, 2012). Content comes to my device-I share it with you, you like it and add it to your device, and so on. This is a potentially significant disruptor to the distribution models on which our TV revenues are based. The content companies will not offer up huge long term financial guarantees if they believe their market models are about to be compromised (Garvin, 2013). And that is just one possibility.

\section{Conclusion}

To conclude, Higher Education signed on the bottom line and drove off the lot in a shiny new convertible. It is time to look carefully under the hood and see exactly what we signed on for. Because we have content that is so valuable and in such demand, we have the power to affect how teams and student athletes are represented in the media. Just waiting for the check to arrive each year and not providing input into how a show is produced, through what lens it is viewed, and the different constituencies we seek to serve is extremely shortsighted. Having worked as a member of a broadcast team, there is little to no difference in producing a professional sports broadcast compared with producing a college sports broadcast. The independent contractors hired treat every job the same. Higher Education needs to have a conversation to ask more questions about what it wants viewers to know about our campuses, not what the networks think it wants. We need to leave behind the excitement of just being on TV and start to tell the partners on what we will not negotiate. Just as many of institutions will not tolerate sweatshop labor or a senior management team devoid of women and minorities, we should not associate in such a visible way with companies whose values are not similar to ours. As leaders and educators, partnering with such a visible and high profitable medium, we should do nothing less. 


\section{References}

NCAA tackling diversity issues with committee. (2006, January). Sports Business Journal.

BTN, China, relationships: A full plate for Daniels. (2012, July 16). Lafayette Journal Courier. Lafayette, Indiana.

Carmin, M. (2012, September 3). BTN: Celebrating five years and looking ahead. Lafayette Journal Courier. Lafayette, Indiana.

Cave, M., \& Crandall, R.W. (2001). Sports rights and the broadcast industry. The Economic Journal, 111, F4-F26. doi:10.1111/1468-0297.00596

Chen, T. (2012). Purdue AD: Big Ten Network paying off. Inside Indiana Business with Gerry Dick. Retrieved from http://www.insideindianabusiness.com/video.asp?id=$1 \&$ type $=$ SPORTS

Clarke, L. (2012, November 18). An analysis of Maryland's potential move to the Big Ten. The Washington Post. Washington, D.C.

Dowd, A. (2012). A bigger ten: In defense of conference expansion. The American: The Journal of the American Enterprise Institute.

Dunn, J.M. (2013). Should the playing field be leveled? Funding inequities among Division I athletic programs. Journal of Intercollegiate Sport, 6, 44-51.

Eshelman, P. (2012, March 18). Emails show extensive efforts to prevent Missouri from leaving Big 12. Columbia Tribune. Columbia, Missouri.

Ey, C. (2013, February 8). Think tickets are expensive? That's just part of what sports costs you. Philadelphia Business Journal.

Flint, J. (2012, August 14). Pac 12 networks add to glut of cable sports channels in L.A. Los Angeles Times.

Fort, R., \& Quirk, J. (1995). Cross subsidizations, incentives, and outcomes in professional team sports leagues. Journal of Economic Literature, 33, 1265-1299.

Garvin, G. (2013, January 26). Watching TV on web is disrupting cable, broadcast worlds. The Miami Herald.

Goetzl, D. (2012, June 18). Longhorn Network launches campaign even as distributors aren't hooked. Media Post.

Johnston, J. (2012, August 26). Big East aims to re-brand itself. The Tampa Tribune.

Kaszuba, M. (2013, January 20). Big Ten is bringing in big money as a TV star. Minneapolis Star Tribune. Minneapolis, MN.

Magnus, B. (2012, December 5). The Changing Face of College Sports. Presented at the IMG Intercollegiate Athletics Forum, New York City.

Martin, M. (2013). The blessings and curses of big time football: One perspective. Journal of Intercollegiate Sport, 6, 52-56.

Newsom, J. (2012). Missrepresentation. Roco Films International.

Nocera, J. (2012, December 10). Show me the money. New York Times. New York.

Noll, R. (2007). Broadcasting and team sports. Scottish Journal of Political Economy, 54(3). doi:10.1111/j.1467-9485.2007.00422.x

Ourand, J. (2009, January 5). Major college conferences and their media rights deals. Sports Business Journal.

Politi, S. (2012, November 19). By joining Big Ten, Rutgers did better than any school in college realignment. Star Ledger. Newark, NJ.

Puskar, G. (2012, August 26). Television is the ruling body for college sports. Pittsburgh Post Gazette. Pittsburgh, PA.

Scully, G. (2008). Sports: The concise history of economics. www.econlib.org.

Smith, M. (2008, August 25). ESPN pays \$2.25B for SEC rights. Sports Business Journal.

Smith, R.A. (2001). Play by play: Radio, television and big-time college sport. Baltimore: Johns Hopkins University Press. 
Stelter, B. (2013, January 25). Rising TV fees mean all viewers pay to keep sports fan happy. The New York Times. New York.

Thompson, D. (n.d.). Prisoners of cable: Why we can't break free from our TV overlords. The Atlantic, (November 2012).

Vorkunov, M. (2012, August 13). Big East hires Chris Bevilacqua as lead negotiator on new TV deal. Star Ledger. Newark, NJ.

Weaver, K. (2009, March). The launch of the Big Ten Network: How 11 universities created their own television network and changed the landscape of college sports. University of Pennsylvania, Philadelphia, PA.

Weaver, K. (2011, Jan/Feb). A game change: Paying for big time college sports. Change: The Magazine for Higher Learning. 